JOANNA KWAŚNIEWSKA-POWROŹNIK* - LUBLIN

\title{
CZASOPISMA W SŁUŻBIE DZIECIOM
}

Pierwsze regularne druki periodyczne pojawily się w Europie na początku XVII wieku, kiedy to zaczęło ukazywać się pismo Nieuwe Tijdinghe oraz Relation Aller Furnemen und Gedenckwüroligen Historien i Aviso Relation oder Zeitung. Na przełomie XVII i XVIII wieku niemal wszystkie kraje Europy miały już pisma periodyczne, ale były one przeznaczone dla dorosłego odbiorcy. Dzieci na swoje czasopisma musiały czekać do drugiej połowy XVIII wieku. We Francji ukazywał się dla nich Ami des Enfants, a w Niemczech Der Kinderfreund. Ein Wochenblatt. Obydwa czasopisma znane były w Polsce, thumaczono je i wydawano seryjnie. Na rodzime czasopismo młody czytelnik musiał w Polsce dość długo czekać. Pustkę tę postanowiła wypełnić dopiero w latach dwudziestych XIX wieku córka literata Ignacego Tańskiego Klementyna wydając Rozrywki dla Dzieci. Podejmując próbe wydania czasopisma Klementyna Tańska miała już za sobą pierwsze sukcesy literackie, wydrukowała w Pamiętniku Warszawskim: Synonimy i zbeletryzowaną rozprawę pedagogiczną Pamiatka po dobrej Matce wydaną bezimiennie ${ }^{1}$. Pamiątka cieszyła się dużą popularnością, dlatego Tańska wykorzystała to podpisując czasopismo nie nazwiskiem lecz jako „Autorka Pamiqtki po dobrej Matce”. Za motto do swej pracy wydawniczej wybrała słowa Alojzego Felińskiego, które zamieszczała na stronie tytułowej w każdym numerze pisma:

Jak słodkie zatrudnienie, giętki umysł wspierać,

Wzbudzać żywą do czynów szlachetnych ochotę,

I gruntować w umyśle nieskażonym cnotę ${ }^{2}$.

Skrępowane przez cenzurę społeczeństwo powitało Rozrywki dla Dzieci z radością, gdyż nie tylko dzieci ale i dorośli znajdowali tam wiele do czytania ${ }^{3}$. Ła-

* Jolanta Kwaśniewska-Powroźnik - mgr bibliotekoznawstwa, kierownik Sekcji Opracowania Alfabetycznego w Oddziale Opracowania Druków Zwartych Nowych Biblioteki Uniwersyteckiej KUL.

${ }^{1}$ I. Kaniowska-Lewańska, Literatura dla dzieci i młodzieży do roku 1864, Warszawa, 1980, s. 60 .

2 „Rozrywki dla Dzieci”, 1 (1924) t. 1.

${ }^{3}$ I. Kaniowska-Lewańska, Literatura dla dzieci, w: Kultura literacka $w$ przedszkolu, red. S. Fryci, I. Kaniowska-Lewańska, cz. 1, Warszawa 1988, s. 115. 
my czasopisma zapełniała niemal w całości Tańska tekstami oryginalnymi jak i obcymi przystosowanymi do polskich warunków i potrzeb, postulowała w nich patriotyczne wychowanie dzieci w warunkach przemian ekonomicznych i społecznych. Sporadycznie zamieszczała też utwory K. Brodzińskiego, Ł. Gołębiowskiego, A. Goreckiego, M. Wyszkowskiego ${ }^{4}$. Miesięcznik drukowany był w Warszawie początkowo w Drukarni Łętkiewicza przy ulicy Senatorskiej 467 a od 1827 roku w Drukarni Gałęzowskiego przy ulicy Żabiey 472. W pierwszym numerze we wstępie Do Dzieci autorka określiła cel wydawania pisma pisząc: „Być wam użyteczną, nauczać was i zabawiać, dopomagać ile w mocy jest mojej do rozkrzewiania w sercach waszych czystej miłości cnoty, ten jest mój zawód cały, to najgorętsze moje pragnienie" ${ }^{5}$. W tym samym numerze Autorka określa częstotliwość ukazywania się pisma i jego objętość: „Rozrywki wychodzą w pierwszym dniu każdego Miesiąca. Każdy Numer zawiera przynajmniej trzy arkusze, co trzy

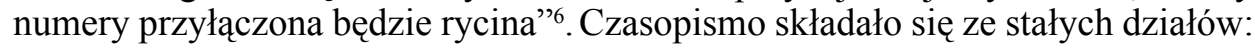
I - Wspomnienia narodowe, II - Powieści, III - Anegdoty prawdziwe o dzieciach, IV - Wyjatki stużace do uksztattowania serca i stylu, V - Wiadomości mogace być matkom przydatne, VI - Przypowieści. Wspomnienia narodowe otwierają każdy numer. Składają się na nie biografie sławnych ludzi np. Grzegorza Piramowicza, Adama Naruszewicza, Alojzego Felińskiego. Przedstawiła tutaj też wizerunki dwu kobiet: Wiadomości o życiu Mari Leszczyńskiej ${ }^{7}$ i Rys życia Marianny z Swidzińskich Lanckorońskiej ${ }^{8}$ oraz powieści drukowane w odcinkach Listy Elżbiety Raczyńskiej i Dzienniki Franciszki Krasińskiej. W dziale Powieści zamieściła 37 własnych opowiadań i 2 Kazimierza Brodzińskiego. Dział III był redagowany z pomocą czytelników, którzy nadsyłali anegdoty. W następnym dziale Autorka zamieszczała wyjaśnienia synonimów, opisy gier salonowych, cykl fikcyjnych listów między rodzeństwem. Dział piąty przeznaczony był dla rodziców i poruszała w nim Tańska wiele istotnych problemów wychowawczych. Redagując ten dział Klementyna Tańska świadomie poszerzała krąg swoich odbiorców o matki. Przypowieści - to krótkie opowiadania, najczęściej o charakterze religijnym. Ogółem ukazało się w latach 1824 - 1828 sześćdziesiąt numerów czasopisma. W ostatnim numerze Tańska informuje czytelników: „Na tym numerze kończy się dziesiąte i ostatnie półroczne Rozrywki. Wydawca chcąc dokonać kilku rozpoczętych prac piśmiennych, które obok tej spoczywać musiały, to Pismo nad zalety swoje mile przyjmowane z żalem przerywa"'. Ostatni numer oprócz stałych działów zawiera Spis prac Ignacego Tańskiego tak drukowanych jak $i$ w rękopisach będacych oraz Spis rzeczy zawartych w 10 tomach tego Pisma.

Czasopismo Tańskiej znalazło szybko naśladowcę w osobie Ignacego Kajetana Chrzanowskiego, który w styczniu 1829 roku z pomocą Stanisława Jachowicza rozpoczął wydawanie Tygodnika dla Dzieci. Chcąc kontynuować jej dzieło za

\footnotetext{
${ }^{4}$ Tamże s. 29.

5 „Rozrywki dla Dzieci”, 1 (1924) t. 1, s. 1.

${ }^{6}$ Tamże, s. 51.

${ }^{7}$ Tamże, 1 (1924) nr 4.

${ }^{8}$ Tamże, 6 (1926) nr 31.

${ }^{9}$ Tamże, 10 ( ) nr 60, 3, okładka.
} 
motto dla swojego pisma przyjął również słowa Alojzego Felińskiego a także dobór treści wzorowany był na Rozrywkach ${ }^{10}$. W odcinkach drukuje cykl z Dziejów Polski potocznym sposobem opowiedzianych Joachima Lelewela oraz powieść Mały Włoch, życiorysy Maksymiliana Fredry, Mikołaja Reja, Stanisława ReweryPotockiego, cykl krajoznawczy Podróż Józia z Warszawy do Szlaska przez niego samego opisana. Problemy wychowawcze poruszone są w Rozmowach ojca z synem Stanisława Jachowicza. Nowością jest objaśnianie przez Kazimierza Władysława Wójcickiego przysłów oraz dział tzw. historii naturalnej, przyrodnicze cykle oraz informacje o książkach, „które dla pożytku dzieci polecić możemy”. W numerze 22 Redaktor informuje: „w tych dniach wyszła z druku książeczka pod tytułem Nauka w zabawce zamykająca w sobie wyjątki z Stasiowego dzienniczka przez S. Jachowicza wydane". Już w następnym numerze rekomenduje: nowe dzieło polskie dla dzieci pisząc: „Dzieje Polski Joachima Lelewela potocznym sposobem opowiedziane, $\mathrm{z}$ których niektóre wyjątki umieściliśmy $\mathrm{w}$ tygodniku, wyszły już z druku z dwunastu mapkami przez samego Autora skreślonymi”. Czasopismo ukazywało się przez rok. Wyszło 48 numerów.

W 1930 roku pojawił się Dziennik dla Dzieci redagowany przez Stanisława Jachowicza. Było to pierwsze w Europie codzienne pismo dla dzieci. Wychodził codziennie oprócz niedziel i świąt, od 2 stycznia do 23-24 grudnia, ogółem ukazało się 299 numerów. Głównym celem redaktora było wychowanie społeczne i poszerzanie wiedzy dzieci i młodzieży. Jachowicz pisze „Dobre przykłady i nauki rozwijają zdolności i uczucia, ale niechże wam braknie na dobrych chęciach, niech się nie zajmie w sercu gorliwość, wtedy wszystko na próżno (...) cnoty uczcie się w czynnym życiu z dobrych przykładów, a przestrogi w książkach zawarte, niech je wam tylko przypominają. Wiadomości naukowe niech was z wolna do myślenia sposobią"1". Nowym elementem pisma są wiadomości aktualne, podawano informacje o książkach i czasopismach (odnotował ukazanie się Ziemomysła i Skarbca dla Dzieci), ciekawostki z pracy dla dorosłych, nekrologi znanych dzieciom poetów, opisywano ważne wydarzenia np. odsłonięcie pomnika Mikołaja Kopernika. W pierwszych dniach powstania najważniejszą sprawą poruszaną w Dzienniku było uświadomienie patriotyczne. W numerze z 4 grudnia pojawił się artykuł Objaśnienie wypadków dzisiejszych, a w następnym numerze Jakim sposobem dzieci mogq okazać sie patriotami ${ }^{12}$.

Przedstawiane wyżej pisma dla dzieci ukazywały się w Warszawie. Pierwszym wydawanym w innym mieście czasopismem był Skarbiec dla dzieci. Tłoczony był w Puławach w Drukarni Bibliotecznej z inicjatywy Izabeli Czartoryskiej. Skarbiec dla Dzieci to pierwsze polskie ilustrowane czasopismo popularnonaukowe dla dzieci. Czasopismo ukazywało się od kwietnia do listopada 1830 roku co miesiąc $\mathrm{w}$ dwu edycjach: $\mathrm{z}$ kolorowymi ilustracjami i czarno-białymi. Pismo przeznaczone było dla dzieci starszych. Tematyka tekstów była bardzo zróżnicowana od przyrodniczych np. Żubr, Bobr, Wieloryby, Papugi dawnego świata poprzez dotyczące techniki: Balon, Okręt, Machiny proste do geograficz-

\footnotetext{
${ }^{10}$ Kaniowska-Lewańska, Literatura dla dzieci i młodzieży, s. 122.

${ }^{11}$ Tamże, s. 124.

${ }^{12}$ Tamże, s. 128.
} 
nych i historycznych: Wysokość gór na kuli ziemskiej, Grecja, Mogiła Kościuszki. Autorzy tekstów podpisywali się inicjałami np. J.L.S. - Jan Leon Sienkiewicz a K. to Karol Sienkiewicz ${ }^{13}$. Każdy numer zawierał stronicowy tekst, który uzupełniały cztery ilustracje. W części drugiej znajdowały się tłumaczenia dzieł zagranicznych, podawane w trzech językach polskim, francuskim i angielskim. Jak pisze redaktor: „Wydajemy te książeczki z tekstami angielskim i francuskim, w nadziei, a nawet w przekonaniu, że przez to ułatwimy początkową naukę tych dwóch języków ${ }^{14}$. Zostały tutaj zamieszczone dwie części eseju Henryś i Lucia R. L. Edgeworth'a. W przedmowie czytamy: „osoby zajmujące się wychowaniem dzieci znajdują tu bardzo szczęśliwe nastręczenia do rozmów, $w$ jakich granicach je zamykać, jaki im nadawać kierunek". Znajduje tutaj czytelnik porady odnośnie postępowania z dziećmi podczas codziennych czynności jak: wstawanie, ubieranie, spacery, zajęcia i zabawy. Na wieść o wybuchu powstania redaktor pisma Karol Sienkiewicz wyjechał do Warszawy i wydawanie czasopisma zostało zawieszone.

Równolegle z Dziennikiem dla Dzieci i Skarbcem dla Dzieci ukazywał się trzeci periodyk dla młodego czytelnika Ziemomyst. Pismo Czasowe dla Dzieci. Redagowany przez Jana Kantego Chruckiego i wydawany jego nakładem, ukazywał się od 15 stycznia do 15 grudnia 1930 roku jako dwutygodnik, drukowany w formacie książkowym w Drukarni Komisji Rządowej. Posiada numerację ciągłą w obrębie kwartału. Słowa A. M. Fredry przyjęte za motto i zamieszczane na okładce każdego numeru mogą świadczyć, że intencją wydawcy była edukacja: „Cudze wiedzieć rzeczy, ciekawość jest, a swoje potrzeba". Tytuł pisma odwołuje się do pierwszych założycieli państwa polskiego, artykuł otwierający pierwszy numer jest $O$ Ziemomyśle, autor prostym językiem nawiązuje do historii Polski. Każdy numer czasopisma rozpoczyna dział Wspomnienia narodowe, znajdujemy tutaj artykuły Kazimierza Władysława Wójcickiego o Stanisławie Koniecpolskim, Janie Dymitrze Solikowskim, Zygmuncie Auguście, Stefanie Chmieleckim, a także o życiu Kurpiów i opis okolic Warszawy. Wydrukowano również z rękopisów utwory Jana Gawińskiego: fragmenty sielanek oraz wiersze Do skowron$k a$, Żale nad zmartym przyjacielem, Do młodego pokolenia, który jest pochwała pracy, Do młodzieży polskiej. Ostatni wiersz jest apelem autora do młodych:

\footnotetext{
Ojczyzny bronić, matki pospolitej

I sławy mieczem odważnej nabytej,

Winieneś jej strzec, rozprzestrzeniać, zdobić

I siłą na jej piękną sławę robić ${ }^{15}$.
}

Podobnie jak w innych czasopismach drukowane są tutaj powieści w odcinkach: Brat i siostra, Opatrzność czyli rozbicie okrętu a w ramach edukacji muzycznej Krakowiaki, Mazurki. Działem stałym w czasopiśmie są Rozmaitości, gdzie zamieszczane są krótkie opowiadania moralizatorskie np. o szabli, o młodym Polaku, który się za króla Władysława Warneńczyka podawał, o pasjach kró-

\footnotetext{
${ }^{13}$ Stownik pseudonimów pisarzy polskich, Wrocław 1995.

${ }^{14}$ Skarbiec dla Dzieci. Puławy, 1830, s. 2.

${ }^{15}$ Ziemomysł. Warszawa, 1830, nr 2, s. 37.
} 
la Zygmunta III. W dziale Historia naturalna ukazały się artykuły: $O$ wielorybach, O oswajaniu pajaka i jaszczurki, Siła owadów, Waż muzykalny. W numerach z czwartego kwartału ukazało się wiele przedruków np. z Dziennika Powszechnego, Kuriera Polskiego. Izabela Kaniowska-Lewańska napisała: „periodyk może być przykładem przyswojenia pewnej techniki wydawniczej, naśladowania już wyrobionych wzorów prasowych, adaptowanych dla młodego pokolenia, jak również pewnej merkantylizacji tego typu wydawnictw"16.

Upadek powstania listopadowego i represje władz zaborczych zahamowały rozwój czasopiśmiennictwa. Cenzura uległa zaostrzeniu i przez dłuższy czas nie uzyskiwano prawa wydawania prasy. Zaborcy zamykali pod byle pretekstem szkoły i zmieniali programy nauczania. Wszystko to budziło obawy o przyszłość młodego pokolenia, dlatego podejmowano próby dostarczania lektury dzieciom i młodzieży. Ukazywały się m.in. noworoczniki, które były bezpieczniejszą formą wydawniczą, gdyż traktowane jako druki zwarte musiały zyskać akceptację cenzury przed wydaniem. Tak Kazimierz Brodziński wydał w 1834 roku Jutrzenkę a Paulina Krakowowa Pierwiosnek (1838 - 1843). Starania o rozwój literatury dla dzieci podejmowano we wszystkich zaborach a także na emigracji. Niestrudzona okazała się Klementyna Tańska Hofmanowa, która próbowała w Poznaniu wznowić Rozrywki dla Dzieci, ale udało jej się wydać tylko jeden tomik. Następną próbę podjęła Autorka w Paryżu wydając Nowe Rozrywki dla Dzieci. Pismo miało ukazywać się kwartalnie, wydała tylko dwa tomiki gdyż zakaz władz carskich z 1833 roku dotyczący sprowadzania do Królestwa Polskiego wydawnictw emigracyjnych zniweczył jej plany. W Królestwie Polskim pierwszym pismem dla młodego czytelnika po powstaniu był Magazyn dla Dzieci. Dziennik użytecznych i przyjemnych wiadomości wydawany jako miesięcznik w latach 1835-1836 i 1845 roku. Następnie ukazywała się w latach 1843-1844 Zorza wydawana przez Paulinę Krakowową i Walentynę Trojanowską oraz przez Józefata Żochowskiego Motyl. W Galicji wychodził Przyjaciel Dzieci. Tygodnik z rycinami, poświęcony nauce i zabawie dzieci, w Poznaniu Szkótka dla Dzieci. Pismo miesięczne poświęcone nauce i rozrywce dla dzieci a w Warszawie Czytelnia Niedzielna.

Przedstawione przykłady pierwszych czasopism świadcza, że powstanie i rozwój prasy dla dzieci związany był ściśle z historią narodu. Dorośli twórcy w trosce o edukację i wychowanie młodego pokolenia starali się dostarczać dzieciom odpowiedniej lektury, wskazywać im drogę rozwoju, rozbudzać marzenia.

${ }^{16}$ Kaniowska-Lewańska, Literatura dla dzieci i młodzieży, s. 131. 


\section{Bibliografia}

Grabowski S., Na przyszty pożytek, Pułtusk 2001.

Kaniowska-Lewańska I., Literatura dla dzieci i młodzieży do roku 1864, Warszawa 1980.

Kultura literacka w przedszkolu, red. S. Fryci, I. Kaniowska-Lewańska, Warszawa 1988.

Łojek J., Prasa polska w latach 1661-1864, Warszawa 1976.

Paczkowski A., Czwarta władza, Warszawa 1973.

Rozprawy z historii literatury dla dzieci i młodzieży, red. K. Kuliczkowska, Wrocław 1958.

\section{ZEITSCHRIFTEN IM DIENSTE DER KINDER}

\section{Zusammenfassung}

Der vorliegende Artikel zeigt die Geburt der polnischen Kinderzeitschriften, und es werden die bis zum Novemberaufstand von 1830 erschienenen Titel besprochen. Die Anfänge der polnischen Zeitschriften für Kinder liegen in den zwanziger Jahren des 19. Jahrhunderts, als periodische Publikationen als ein vorzügliches Werkzeug im Prozess der Bildung und Erziehung der jungen Generation Anerkennung fanden. Die Autorin und Herausgeberin der ersten Kinderzeitschrift war Klementyna Tańska, die ihre „Rorzywki dla Dzieci” (,Zerstreuungen für Kinder”) an die jungen Leser adressierte. Diese Zeitschrift erschien von 1824 bis 1828 und erlebte insgesamt 60 Nummern. Weitergeführt wurde das Werk von Klementyna Tańska dann von Ignacy Kajetan Chrzanowski, der mit Hilfe von Stanisław Jachowicz 1829 mit der Herausgabe des „Tygodnik dla Dzieci” (,Wochenblatt für Kinder") begann. Diese Zeitschrift erschien ein Jahr lang und umfasste 48 Nummern. Das Jahr 1830 brachte den Kindern drei Titel: „Dziennik dla Dzieci” (,Tageblatt für Kinder”), „Skarbiec dla Dzieci” (,Schatzkammer für Kinder”) und „Ziemomysł. Pismo Czasowe dla Dzieci” (,Ziemomysł. Zeitschrift für Kinder”). „Dziennik dla Dzieci” wurde von Stanisław Jachowicz in Warschau herausgegeben. Ebenfalls in Warschau erschien „Ziemomysł” unter der Redaktion von Jan Kanty Chrucki. Die erste außerhalb Warschaus herausgegebene Kinderzeitschrift war „Skarbiec dla Dzieci” - sie wurde auf Initiative von Izabela Czartoryska in der Bibliotheksdruckerei in Puławy gedruckt. Die Repressionen der Teilungsbehörden nach der Niederschlagung des Novemberaufstandes hemmten die Entwicklung der an die jungen Leser gerichteten Zeitschriften. Klementyna Tańska versuchte, „Rozrywki dla Dzieci” zu reaktivieren, aber es gelang ihr lediglich, noch eine Nummer in Posen und zwei weitere in Paris herauszugeben. Im Königreich Polen (Kongresspolen) erschienen „Magazyn dla Dzieci” („Magazin für Kinder”) und „Zorza” („Morgenrot”) und in Galizien „Przyjaciel Dzieci” (,Der Kinderfreund”). 